\title{
EXPORT OF AGRICULTURAL AND FOOD PRODUCTS IN THE FUNCTION OF ECONOMIC GROWTH OF REPUBLIC OF SERBIA
}

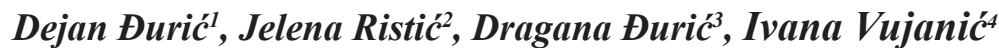

\begin{abstract}
Summary
A low export activity and a high level of trade deficit are negative features of the Serbian trade with foreign countries in the long run. Considering the state of foreign trade flows of our country, it is clear that the increase in exports of goods and services is emerging as one of the most important tasks of economic policy in the years to come. In this sense, the main goal of this work is the understanding of the importance of the agricultural and food products sector in foreign trade of Republic of Serbia, as well as proposing of measures to be taken towards encouraging export and raising competitiveness of the sector in the international market.

Agricultural and food sector can significantly contribute to reduction of the trade deficit and boost the export activities of the national economy. However, the potentials of this sector have not yet been fully utilized. Although exports of agricultural and food sector have a dominant position in the structure of domestic exports, its competitiveness is still at a low level, and the increase of competitiveness and the degree of processing of these products stand out as the key challenges in the future.
\end{abstract}

Key words: export, agricultural and foodsector, globalization, international competivness

JEL: $Q 17, F 49$

1 Dejan Đurić, Ph.D., Professor, Business School of Applied Studies Novi Sad, Vladimira Perića Valtera Street, no. 4, 21000 Novi Sad, Republic of Serbia, Phone: +381 638057 420; E-mail:ddjuric971@gmail.com

2 Jelena Ristić, Ph.D., Professor, Business School of Applied Studies Blace, Kralja Petra I Street, no. 70, 18420 Blace, Republic of Serbia, +381 63404 202; E-mail:jelenazristic@yahoo.com

3 Dragana Đurić, Ph.D., Professor, Business School of Applied Studies Blace, Kralja Petra I Street, no. 70, 18420 Blace, Republic of Serbia, +381 658057 420; E-mail:djdragana@ikomline.net

4 Ivana Vujanić, Ph.D. student at the European University in Belgrade, Faculty of European Business and Marketing, Carigradska no. 28, Belgrade, Serbia Phone: +381 6297928 66, E-mail: ivanavujanic3@gmail.com

EP 2017 (64) 3 (887-900) 


\section{Introduction}

Contemporary international economic environment is characterized by the globalization process of national and regional markets as a result of accelerated internationalization in the global plan. Intensive technological changes and the general scientific progress constantly strengthen the intensity of the globalization process so that it becomes the dominant economic and political phenomenon of the modern world.

National markets cannot be isolated from foreign competition in modern international economic relations to, so that countries and companies need a new approach to inclusion into the globalized and competitive economic environment. The globalization of the world economy imposes the need for all countries to be more intensively involved in international trade flows, i.e. the exchange of goods, services, labor and capital. Adjustement to the challenges of globalization is an important task for all countries to be able to fulfill their primary economic objective, and that is the growth of living standards of all citizens. In this regard, strengthening export activity is emerging as one of the most important conditions for increasing the economic activity of a country.

Agricultural and food sector has a very important role in the economic development of Republic of Serbia, considering that it significantly participates in the structure of domestic exports. Serbia has the potential for production and processing of high quality and healthy products and development of conventional, integral and organic agricultural production for the needs of the domestic market and export (Cvijanović et al., 2016). In this regard, the creation of a competitive agricultural and food sector can greatly contribute to strengthening the overall competitiveness of the domestic economy and its active participation in the international exchange of goods. There are chances for intensifying export activities of this sector above all, thanks to the available natural and human resources, as well as the relatively high level of agricultural techniques and technologies. Due to the scientific and technological revolution, especially from the middle of the last century on, there have been certain changes in the agricultural activity by its mechanization and usage of chemical substances, which relates to the contents and kind of work in the agriculture...(see: Cvijanović et al., 2013). However, there are serious limitations, such as low level of labor productivity, inadequate agricultural policy and insufficient investments in the sector of agriculture.

\section{Methodology}

Theoretical elaboration and the goals have influenced the authors of this paper to use the descriptive, comparative-historical and analytical-synthetical methodology, whereby an attempt was made to consider and understand the problem. Moreover, the analysis of the contetnt of the adopted documents and the results of previous research was used. The basic data sources are represented by the statistics of the external trade. Materials of the Ministry of Finances of Republic of Serbia, Chamber of Commerce of Serbia, Statistical Office of Republic of Serbia and other relevant sources. 


\section{The need to strengthen the export activities of the tradable goods sector}

Republic of Serbia, as a relatively small country with an underdeveloped economy and scarce development resources must be export-oriented, with a developed tradable sector (agriculture and industry). The Serbian economy is not only uncompatitive due to the lack of sufficient high quality products to be launched on foreigh markets, but due to the state's non activities, while the unioins do not support the employers sufficiently in their claims for a better economic environment (Cvijanović, Mihailović, 2012). In such a country there is a need for an increase in exports due to the following reasons:

- the limitations of the domestic market cannot provide the economies of scale, and thus one of the most important conditions for strengthening the competitive position of domestic companies on the world market;

- lack of basic production inputs and the necessity of meeting the needs of all citizens, through purchase of goods and services, will inevitably lead to the growth of imports, which also increases the need for greater exports to the foreign trade sector to be held in balance. A small country cannot provide a range of goods wide enough and therefore has to import and provide the required level of exports for payments of imports.

Considering the importance of export for Republic of Serbia, it is obvious that witout its growth Republic of Serbia cannot realize its basic economic goals. In that sense, the main task of economic policy in the forthcoming period is the increase of exports in order to:

- Increase production and thus the employment and the living standards of the citizens;

- Provide macro economic stability by the reduction of sensitivity of economic growth depending on the inflow of capital;

- Enable regular service of external debt (Strategy of increasing exports of Republic of Serbia for the period from 2008 to 2011).

To continuously achieve high rates of economic growth and a constant increase in gross domestic product and the standard of living, Serbia must constantly and rapidly increase its exports. The increase in export revenue is an important condition for service foreign debt and provide financing for the import of equipment and technology, and that means a prerequisite for economic development in the years to come. The projected dynamic growth of external debt payment shows that in the future for regular servicing of debt obligations an increased share of GDP will be allocated.

The economy of Serbia in the period after 2000 achieved a relatively high level of foreign currency reserves. However, with the increase in debt repayments falling due in the coming years, the pressure on foreign exchange reserves will grow, so it is necessary to insist on the augmentation of exports as the best way of financing the deficit of the trade balance. Also, one should not underestimate the fact that foreign exchange inflows from remittances of our workers abroad cannot be indefinitely increased, that based on exchange operations foreign exchange inflows cannot be indefinitely increased, so that in the long term, only the increase of exports and reduction of trade deficit can provide 
a satisfactory basis for regular servicing of foreign debts without compromising the country's external liquidity.

The increase in exports of goods and services in GDP is imposed as one of the most important tasks of economic policy in the coming years. This task is especially important because of the need to ensure a stable foreign currency income which will be sufficient for regular servicing of foreign liabilities, as well as payment of necessary imports. In order to achieve this, it is necessary to work towards achieving qualitative changes in the structure of domestic exports and to adapt global demand for imports. This means that the increase in exports at the same time must be accompanied by qualitative structural changes in exports, due to the fact that the national export is now too much based on primary products and products of lower processing phase. Such export structure does not promise a permanent and long-term growth rate of exports.

The basic measure of the competitiveness of modern economies is the ability of companies, industries and sectors of the economy to lower operating costs and development and thus achieve economic competitiveness, i.e. competitiveness on the basis of price, and the ability of companies, industries and sectors of the economy to improve performances of products and services, above all, quality, functions and after-sales service. Based on this criteria, the majority of the Serbian economy has no satisfactory ability to reduce costs and improve product quality and, consequently, does not reach the necessary economic and technological competitiveness in domestic and foreign markets (Đurić, 2007). In this regard, the fundamental problems of low competitiveness of domestic exports can be resolved only by entrepreneurs, innovators and investors in a stimulating economic environment. On these grounds, the production, export and technological performance of the Serbian economy would be improved and the level of its international competitiveness would be raised.

Export growth in the long term implies an increase in competitiveness of the economy based on productivity growth, wage growth in line with productivity growth as well as a real exchange rate that reflects the strength of the economy. Also, any Serbian company must see its comparative advantages and potentials and work on developing its own strategies of competitiveness in regional and global markets, and this necessarily means an increase in added value products or services. The key instruments for achieving these objectives are the application of knowledge and innovation in product development, design application, investment in new technologies and distribution channels.

The formation of clusters is, for example, one of the possibilities to increase Serbian exports, particularly to large markets that need large quantities of certain goods (especially in agriculture). More companies should produce the same products at the same given the standards required by the market that they are intended to. The formation of regional clusters is one of the measures of the regional development of Serbia and the way to formation of local brands. The possibility that the higher forms of cooperation with countries with developed economies should be considerd and thus take advantage of the preferential status of our goods to the Russian market and other markets (Nikolić, 2014). 
Special importance to reduce the foreign trade imbalance in the coming period will have a high inflow of foreign direct investments, especially greenfield investments in export-oriented sectors of the economy in which they need to increase productivity, exports and foreign exchange inflows. These sectors strengthen the export offer and reduce import demand and consequently improve the balance of payments position of the country and lead the financing of the current account deficit without increase of government borrowing. A key role in this is the inflow of foreign direct investments into the tradables sector.

\section{Scope and dynamics of foreign trade flows after 2000}

As a result of the re-inclusion of our country in the international economic environment there was a revival of foreign trade activities in Serbia after 2000. The long isolation from the world market and the inability to come up with necessary products caused a strong need for dynamic import of goods and services, which led to an increase in trade deficit and current account deficit.

Based on the data on trends in foreign trade sector of the Serbian economy after 2000, we can conclude that after 2000 the basic feature of the trade balance of our country was a high level of foreign trade deficit. It reflected at a relatively high level of above $20 \%$ of GDP, and in 2004 amounted up to $30 \%$ of GDP.

Table 1. Foreign trade balance of Republic of Serbia for the period from 2001 to 2014 (mil.USD)

\begin{tabular}{|c|r|r|r|r|c|}
\hline Year & Exports & Imports & Balance & $\begin{array}{c}\text { Export-import } \\
\text { ratio (\%) }\end{array}$ & $\begin{array}{c}\text { foreign trade } \\
\text { deficit as\% of } \\
\text { GDP }\end{array}$ \\
\hline 2001 & 1720 & 4260 & -2540 & 40 & 21 \\
\hline Year & Exports & Imports & Balance & $\begin{array}{c}\text { Export-import } \\
\text { ratio (\%) }\end{array}$ & $\begin{array}{c}\text { foreign trade } \\
\text { deficit as\% of } \\
\text { GDP }\end{array}$ \\
\hline 2002 & 2074 & 5614 & -3540 & 36 & 22 \\
\hline 2003 & 2756 & 7477 & -4721 & 36 & 24 \\
\hline 2004 & 2523 & 10755 & -7232 & 32 & 30 \\
\hline 2005 & 4480 & 10461 & -5981 & 41 & 24 \\
\hline 2006 & 6431 & 13174 & -6743 & 48 & 23 \\
\hline 2007 & 8823 & 19165 & -10342 & 46 & 25 \\
\hline 2008 & 10974 & 24332 & -13358 & 45 & 25 \\
\hline 2009 & 8345 & 15808 & -7463 & 52 & 19 \\
\hline 2010 & 9794 & 16471 & -6677 & 59 & 17 \\
\hline 2011 & 11780 & 19862 & -8082 & 59 & 17 \\
\hline 2012 & 11229 & 18928 & -7699 & 59 & 19 \\
\hline 2013 & 14612 & 20553 & -5941 & 71 & 13 \\
\hline 2014 & 14845 & 20650 & -5805 & 71 & 13 \\
\hline
\end{tabular}

Source: http://webrsz.stat.gov.rs/WebSite 
Based on the movement of foreign trade flows in recent years, we can see that the share of goods exports almost continuously increases, which, along with the stabilization of the share of goods imports, led to a substantial decline in the share of foreign trade deficit. However, this does not at all mean that there has been a significant improvement in export activities in our country. It can be concluded on the basis that the export of Serbia in relation to GDP is still considerably lower than in similar countries of Central Europe. While in Serbia, export of goods and services in 2014 amounted up to $44 \%$ of GDP, the share of exports in GDP in countries of similar size (Bulgaria, the Czech Republic and Hungary), in the same year was about $80 \%$. Starting from the level of external debt of the country and the need to import raw materials and intermediate goods for domestic production, export ratio could have reached a value above $50 \%$ of GDP (Ministry of Finance of Republic of Serbia). Therefore, Serbia has a great potential for growth in exports and reduction of the trade deficit on this basis. In addition, export growth is a key drive of sustainable growth of the Serbian economy in the coming years, and double-digit growth rates of exports would be a signal that Serbia is on a sustainable path of growth (Quarterly Monitor, 2015).

Considering the fact that from the standpoint of the economic interests of our country it is very important to intensify and strengthen the export competitiveness of the economy at the global level, in the next part we pay the attention to the economic importance of the agricultural and food sector as a development opportunity of the domestic economy.

\section{Dynamics of foreign trade of agricultural and food products}

The agricultural sector has a significant share in the total foreign trade, and the results achieved in this sector can influence the improvement of foreign trade balance and balance of the total national economy (Katić, Popović, 2007). As noted earlier, the basic feature of the trade balance of our country after 2000 is a high level of foreign trade deficit. However, unlike the other sectors, the sector of agricultural food products in the overall structure of goods exchange has a positive balance, causing a decrease of the total trade balance deficit and contributes to the overall macro-economic stability.

Table 2. Foreign trade agricultural exchange of Serbia (mil.EUR); 2008-2013

\begin{tabular}{|l|c|c|c|c|c|c|}
\hline & $\mathbf{2 0 0 8}$ & $\mathbf{2 0 0 9}$ & $\mathbf{2 0 1 0}$ & $\mathbf{2 0 1 1}$ & $\mathbf{2 0 1 2}$ & $\mathbf{2 0 1 3}$ \\
\hline Export & 1,336 & 1,395 & 1,700 & 1,956 & 2,131 & 2,104 \\
\hline Import & 1,056 & 991 & 819 & 1,053 & 1,221 & 1,177 \\
\hline
\end{tabular}

Source: Statistical Office of the Republic of Serbia

The largest trade balance was recorded in 2013 and it amounted 927 million euros, which is $2 \%$ higher than the surplus achieved in 2012 (910 million euros). Foreign trade of agricultural and food products in the observed years is in a constant rise (Report on the state of agriculture in Republic of Serbia in 2013). The share of agriculture in total export value of the Serbian economy is about 23\% higher than the share of agriculture in imports, in some years, even triple. 
Table 3. Share of agricultural and food sector in foreign trade balance of Republic of Serbia in the period from 2008 to 2013

\begin{tabular}{|l|c|c|c|c|c|c|}
\hline & $\mathbf{2 0 0 8}$ & $\mathbf{2 0 0 9}$ & $\mathbf{2 0 1 0}$ & $\mathbf{2 0 1 1}$ & $\mathbf{2 0 1 2}$ & $\mathbf{2 0 1 3}$ \\
\hline Share of agriculture in total Serbian exports (\%) & 18 & 23.4 & 23 & 23.2 & 24.1 & 23.4 \\
\hline Share of agriculture in total Serbian imports (\%) & 6.5 & 8.7 & 6.6 & 7.4 & 8.3 & 8.2 \\
\hline Coverage of imports by exports (in\%) & 126.5 & 140.8 & 207.6 & 185.8 & 147.5 & 178.8 \\
\hline
\end{tabular}

Source: Strategy for Agriculture and Rural Development of the Republic of Serbia for the period 2014-2020. (2014) Belgrade: Ministry of Agriculture. Taken from http://uap.gov.rs/wp-content/ themes/uap/STRATEGIJA\%202014-2020\%20.pdf

Based on the indicators of foreign trade in agricultural and food products presented in the previous table, it can be seen that Serbian agricultural foreign trade represents nearly one-quarter of the total domestic export, with a very high a trade balance, and as such it is clearly a very serious potential for economic development and the total macroeconomic and social stability. The intensification of export activities of agricultural and food products was continued in the following years. According to Serbian Chamber of Commerce, the total foreign trade of agriculture in 2016 amounted up to 4173.7 million EUR. Balance of trade in agriculture and food industry of Serbia with foreign countries in 2016 shows the value of export of 2898.8 million EUR, which represents an increase of $11.9 \%$ compared to the results for the same period in 2015, with the share in total exports of $21.6 \%$. The value of imports in the amount of 1274.9 million EUR was $10.7 \%$ lower than in the first twelve months of 2015, with the share in total goods imports of $7.3 \%$. The surplus in foreign trade in agricultural and food products in the period January - December 2016 amounted 1623.9 million EUR with an increase of 39.7\% compared to the same period in 2015, and rate of coverage of imports by exports was $227.7 \%$ (www.pks.rs).

The trend of deficit reduction in the area of agricultural and food production was the result of action of several factors. The most significant among them is the preferential status that Serbia has received from the European Union in November 2000. Based on this agreement, the export of agricultural and food products of domestic manufacturers (except for certain types of fish, wine and cheese) was exempt from all charges during the marketing in the EU. Another important factor is signing of several important free trade agreements with neighboring countries (Bosnia and Herzegovina, Macedonia, Croatia, Albania, Moldova, Bulgaria and Romania). Serbia in 2006, replaced the existing bilateral agreements with one under the CEFTA (Central European Free Trade Agreement). Relatively favorable results of Serbian agriculture in foreign trade exchange were achieved thanks to the benefits that it has and achieved trade liberalization, as well as the economic boom, which is improving in the world market (demand growth).

Also, Serbia enjoys the privilege of one of the few countries in the region which has been enabled by free trade with Eusko Federation, and by 2005 the United States approved a General preference agreement that approved free access of Serbian agricultural and food products to the US market (Report on the agriculture in the Republic of Serbia in 2013). 


\section{Goods and geographical structure of agricultural and food products exports}

In the total export of agricultural products of Serbia in 2016 the commodity group of vegetables and fruits with $25 \%$ dominates, then the cerealwith a slightly lower share $(22 \%)$, and tobacco (11\%), oil (6\%), and beverages $(6 \%)$.

It is indicative that there is a very small share of meat and other animal products (milk, cheese, eggs, etc.). Agricultural exports are dominated by raw materials and intermediate goods. There is little participation of final products, which qualifies Serbian agriculture as a raw material supplier. It means that products of higher levels of processing are still imported and that unnecessarilly reduces trade surplus that is accomplished by the agricultural and food sector. This significantly affects the profitability of achieved exports. Namely, produts of a higher level of processing have a dominant position in the structure of highly developed countries exports.

Figure 1. Structure of export of agricultural and food products of the Republic of Serbia in 2016
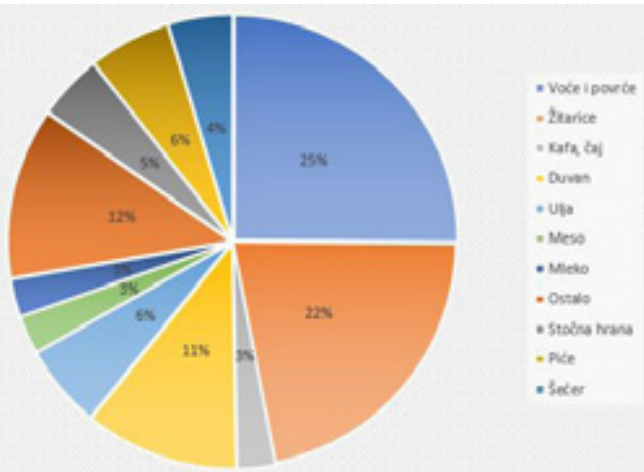

Source: Serbian Chamber of Commerce (2016). Agriculture, food and tobacco industry and water-statistics. Belgrade. Taken from: http://www.pks.rs/PrivredaSrbije.aspx?id=13\&p=2\&

The largest exporters in the agricultural and food sector in our country are the following companies: "Sojaprotein", "Viktoriaoil", "MK Commerce, sugar industry" "Crvenka", "Diamant', "Danubius”, "SwisslionTakovo", "Delta Agrar”, PIK “Bečej”, "Coca-Cola Hellenic”, "Imlek", "Sunoko”, “Apatinska pivara”, "Dijmant”, "Pionir”, "Carlsberg Serbia", "Knjaz Milos", "Jaffa", "Frikom”, "Bambi Banat", "Nectar”, "Vital”, "Mlekara Šabac", "Marbo Product", "Rauch Serbia"...(Vlahović, 2015).

Foreign trade exchange of agricultural and food products of the Republic of Serbia is mainly realized with the European Union (half of the exports of agricultural and food products is carried out with the EU) and CEFTA countries, and a small part with the Russian Federation. The aforementioned market in 2015 with a share of total Serbian foreign trade of food $85.5 \%$, out of which their share is $89.2 \%$ in total exports, while total imports of their share is $78.4 \%$ (RSO, Database of foreign trade, 2016). 
Since 2001, Serbian agriculture has had a positive trade balance in trade with the EU. The surplus in the trade has a tendency of growth year to year, so it wasincre ased to 1,027 million in 2014 when compared to 170 million dollars in 2001. The agriculture exports of Serbia in the EU in 2015 were represented with $47.7 \%$, and the dominant export products were primary agricultural products (raw materials) - about 94\%.

Such a geographical structure of agricultural and food products exports shows a very low geographical diversification of exports and the huge dependence on the economic and political situation in the European Union, as the most important Serbian foreign trade partner. Although the European Union has approved the abolition of all quantitative restrictions, customs duties and taxes on imports (except beef, sugar and wine) (Aničić, Simić, 2017), Serbia fails to increase the level of finalization of products exported to this economic integration. Mainly they are raw materials, i.e. fresh and frozen fruits and vegetables, as well as cereals, although there is a purchasing demand on the level of the European Union.

Another important foreign trade partner of Serbia is the region of the Southeast Europe (CEFTA countries). Due to the proximity of the market and traditional integration, this region is a very important market for agricultural and food products from Serbia. Balance of trade in agriculture and food industry of Serbia with the CEFTA countries in 2015 shows that export in value of 920 million dollars was realized. At the same time, the value of imports was in the amount of 173 million dollars. Surplus in foreign trade of agricultural and food products in that period was 747 million dollars. CEFTA agreement enables market expansion and trade under the same conditions for all countries, opens up a larger market for investments and creats agencies that are competent for management in this area (Vidović, Milunović, 2017). This agreement allows the Serbian businessmen to sell goods without customs duties on the market that includes about 30 million people, and increases the chance for appearance on European markets (Đurić et al., 2016). Observed by countries within the CEFTA region, the most part is exported to Bosnia and Herzegovina, and a large export is realized in Macedonia and Montenegro. The structure of foreign trade exchange, when we talk about these countries, is far different from the exchange with the European Union, because it is about products of a relatively higher level of product finalization. The essential fact is that Serbia is, when compared to all the signatory countries of CEFTA, a net exporter of food, while the main export products are cereals, ie.products from cereals.

Among other countries, the most important export partner is the Russian Federation. Republic of Serbia is one of the few countries in Europe that has signed a free trade agreement with the Russian Federation that allows free access to the Russian market for our agricultural and food products. There is a fundamental problem in the foreign trade of agricultural and food products with the Russian Federation - the inability to fill quotas and satisfy a large contingent of goods required from retail chains in the country. A larger share of final products, ie.food products are noticeable in the structure of trade with Russia. 


\section{Proposal of measures for exports boosting}

The global economic and financial crisis has shown that the then current model of economic growth of the Republic of Serbia which was essentially based on growing domestic consumption and imports and a small share of exports and investments in the structure of GDP use was untenable. It became apparent that such a model should be replaced by the pro-investment and export-oriented model of economic growth. This means that a new model of economic growth that should allow changes in the structure of creation and use of GDP in the strengthening of tradables sector must be formulated.

Strengthening the tradables sector (agriculture and manufacturing) involves primarily the technological modernization according to the EU standards and productivity growth and living standards respectivly. This sector needs to gain a competitive advantage in the market products with high added value, instead of the production and export of raw materials and semi-final products. Much of the Serbian economy is lagging behind the developed countries due to a long period of disinvestment and spending of depreciation spending and neglect of innovation and knowledge as a development resource, which resulted in low exports values, high deficit in the current balance, depreciation of the dinar and rising debt (Bošnjak, 2011).

The main problems of domestic exports are:

- export structure is based on domination of reproduction products i.e. product of low degree of processing,

- generating a low level of concentration, in spite of a relatively small value the total export,

- the lack of competitiveness of export supply in terms of products (product design and development; technical standards; durability and appearance, presentation) and in terms of price (the price of raw materials, financing costs, taxes and transport).

- export activities of several enterprises determine the overall dynamics of exports,

- the production and export of the food industry are largely influenced by meteorological conditions (genus farming)

- there is a significant correlation between exports and imports, and thus the largest exporters are also the biggest importers at the same time.

Thus, there are numerous problems which limit the powerful boosting of export activities of Serbian economy. A first highlight is an inadequate structure of the domestic economy, i.e. unfavorable structure of exports which cannot provide sufficient competitiveness in the international market. The export structure of our country is still dominated by products for reproduction i.e. products of a low degree of processing, and the structural changes in the real sector are fundamental prerequisite to raise the export to the higher level of competitiveness. In this sense, Serbia needs a fundamental change in export structure towards increasing the participation of higher finalization of the products, as 
done by more advanced transition countries that are already in the European Union.

A more intense appearance in the international market of agricultural and food products in the future must be based on:

- strategic concept of developmental and export-oriented agriculture,

- improving the competitiveness of goods of agricultural origin,

- improving the quality of products and

- commitment to further liberalization of international trade.

The concept of increasing exports of agricultural and food products, in addition to stable and sustainable growth in production should include the adjustment of the export structure requirements of import demand and improve the competitiveness of exports using comparative advantages in exports, based besides to the agro-ecological potential and technological modernization, on improving the concept of education, management and organizational knowledge and experience. In order to increase the competitiveness of Serbian agriculture proposes the following are being suggested:

- growth of the multiple economies in the structure of overall agriculture in order to simultaneously increase the productivity of agricultural sector;

- reorganization of the agricultural market with the aim of reducing the monopoly on the demand side, in order to ensure stability, and the price competitiveness of the export;

- increase the agricultural budget with much greater participation of subsidies (Petrović, 2013).

Liberalization of the market in our country has led, as we have pointed out before, to the growth of foreign trade of agricultural and food products, so in this context, improving the competitiveness of domestic agricultural production and processing industry by increasing productivity, efficiency and technological standards of production, will form the basis to maintain and improve the positive foreign trade balance in the field of agricultural and food products (Birovljev et al., 2015).

Production and technological restructuring and productivity growth as well as greater competition in the domestic and international markets, should be based on environmental, energetic and economic criteria. At the same time, the development of scientific research and the application of existing and new knowledge and technologies will create conditions for a significant increase in the volume and cost of this production. Strict implementation of the national program for the development of agricultural production, food processing, and comprehensive development of villages, modern and industrialized agricultural production and food industry would constitute the basis of the rapid development of the entire economy and contribute to faster development of other branches of industry and infrastructure. 
In recent years as one of the most important sources of competitiveness of the agricultural sector the creation of brands, or brands, is also mentioned. In this regard, it is important to point out that the efforts to make a brand that can be competitive on the world market from products typical of our area have to be made. In order to succeed, it is necessary to develop a branding strategy, improve the level of processing of the products and their packaging. When the traditional products are in question, it is necessary to work on the protection of geographical origin of the products and branding of certain regions and areas. Besides the registration of the mark geographic origin, it is necessary to improve and strengthen marketing activities and strengthen additional promotional activities by the state authorities.

\section{Conclusion}

Achieving high rates of economic growth and a stable increase in gross domestic product and the living standard of Republic of Serbia a strong involvement of the country in the international division of labor and strengthen its export activities must be included. The increase in export revenue is an important condition for servicing high levels of external debt and provision of finacing for the import of equipment and technology, and that means a prerequisite for economic development in the years to come. In this sense, the sector of agricultural and food products has an extremely important role, and creating a competitive market of agriculture can greatly contribute to the strengthening of export potential of the domestic economy. Since Republic of Serbia faces a long-term deficit of the trade balance, the improvement in foreign trade of agricultural and food products is becoming a necessity. In this way it is necessary to radically change the structure of exports in order to enhance the competitiveness of these products and to remove limitations which are the result of low labor productivity, inadequate agricultural policy in the past decade and the lack of funds for investment in the sector of agriculture.

\section{Literature}

1. Birovljev, J., Matkovski, B., Ćetković, B., (2015): Konkurentnost poljoprivrednoprehrambenih proizvoda Srbije na tržištu zemalja regiona, Anali Ekonomskog fakulteta u Subotici, p. 61-78, Republika Srbija.

2. Bošnjak M., (2011): Globalna ekonomska $i$ finansijska kriza i njen uticaj na privredu i finansije Srbije, Ministarstvo finansija Republike Srbije, Beograd.

3. Cvijanović, D., Ignjatijević, S., Milivojević, I., Mihailović, B., (2016): Potencijali Srbije u međunarodnim okvirima - značaj poljoprivrede i zdravstvenog turizma, Monografija, Fakultet za hotelijerstvo i turizam u Vrnjačkoj banji, Republika Srbija.

4. Cvijanović, D., Popović, V., Subić, J., Paraušić, V., (2013): Stanje i mogućnosti razvoja održive poljoprivrede $i$ ruralnog razvoja u podunavlju, Monografija, Institut za ekonomiku poljoprivrede Beograd, Republika Srbija. 
5. Cvijanović, D., Mihailović, B., (2012): Međunarodni marketing kao factor razvoja izvozne konkurentnosti, Monografija, Institut za ekonomiku poljoprivrede Beograd, Republika Srbija.

6. Đurić, D., Ristić, J., Đurić, D., (2016): Foreign Direct Investments in the Role of Strengthening the Export Competitiveness of the Serbian Economy, Economics of Agriculture, Vol. 63, No. 2 pp. 357-740, ISSN 0352-3462, Belgrade, p. 531-546.

7. Đurić, D., (2007): Jačanje i unapređenje izvoznih aktivnosti kao najvažniji cilj ekonomske politike u 2007. godini, Konferencija - Izazovi ekonomske politike Srbije u 2007. godini, Zbornik radova, Naučno društvo ekonomista sa AEN i Ekonomski fakultet u Beogradu, Beograd, p. 273.

8. Katić, B., Popović, V., (2007): Dinamika i struktura razmene poljoprivrednoprehrambenih proizvoda između Srbije i Evropske unije u periodu 20002006.godine. Ekonomika poljoprivrede, Vol. 54, No. 3, p.303-320, Institut za ekonomiku poljoprivrede Beograd, Republika Srbija.

9. Aničić, A., Simić, M. (2017): Tobinov porez u EU, Oditor, Vol. 3, No. 2, pp. 100106.

10. Kvartalni monitor No. 40, 2015. (available at: https://www.fren.org.rs/sites/ default/files/qm/T-4 0.pdf)

11. Ministarstvo poljoprivrede i zaštite životne sredine, Izveštaj o stanju u poljoprivredi u Republici Srbiji u 2013.godini, Republika Srbija, Beograd (available at: http:// webrzs.stat.gov.rs.beg.org.rs/Komora/OpstaA.aspx?veza=14305)

12. Nikolić G., (2014): Dinamika i kvalitativne promene robne razmene Srbije Ključna karika napretka, Okosnica nove razvojne strategije Srbije: bez izvoza nema izlaza

13. Petrović, J., Jovanović, D., Petrović, D., Berjan, S., (2013): The impact of Serbian agriculture exports on its trade deficit. Fourth International Scientific Agricultural Symposium "Agrosym” 2014 Jahorina (Bosna i Hercegovina): Poljoprivredni fakultet Univerziteta Istočno Sarajevo, p. 1356-1362, Bosna i Hercegovina

14. Privredna komora Srbije, Spoljnotrgovinska razmena poljoprivrede i prehrambene industrije Srbije sa svetom u 2016. (available at: http://www.pks.rs/SADRZAJ/ Files/Poljoprivreda/Razmena\%20agrara \%20za\%20period $\% 20 \mathrm{I} \% 20-\% 20 \mathrm{XII} \% 20$ 2016\%20\%20godine.pdf)

15. Privredna komora Srbije (2016). Poljoprivreda, prehrambena $i$ duvanska industrija $i$ vodoprivreda-statistika. Beograd. (available at: http://www.pks.rs/ PrivredaSrbije.aspx?id=13\&p=2\&)

16. Republički zavod za statistiku Srbije (2016). Baza podataka o spoljnoj trgovini, Beograd. (available at: http://webrzs.stat.gov.rs).

17. Strategija povećanja izvoza Republike Srbije za period od 2008. do 2011. godine (available at: http://www.srbija.gov.rs/vesti/dokumenti_sekcija.php?id=45678)

18. Vlahović, B., (2015): Tržište agroindustrijskih proizvoda, Univerzitet u Novom 
Sadu, Poljoprivredni fakultet, Republika Srbija

19. Vidović, Z., Milunović, M. (2017): Revizija svrsishodnosti poslovanja, Oditor, Vol. 3, No. 2, pp. 37-53.

20. Foreign trade balance of Republic of Serbia: http://webrsz.stat.gov.rs/WebSite

\title{
IZVOZ POLJOPRIVREDNO-PREHRAMBENIH PROIZVODA U FUNKCIJI EKONOMSKOG RASTA REPUBLIKE SRBIJE
}

\author{
Dejan Đuric ${ }^{5}$, Jelena Ristic ${ }^{6}$, Dragana Đurićc , Ivana Vujanic ${ }^{8}$
}

\section{Rezime}

Niska izvozna aktivnost i visok nivo trgovinskog deficita, negativno su obeležje trgovinske razmene Srbije sa inostranstvom u dužem vremenskom periodu. Imajući u vidu stanje spoljno-trgovinskih tokova naše zemlje, jasno je da se porast izvoza roba i usluga nameće kao jedan od najvažnijih zadataka ekonomske politike u narednim godinama. U tom smislu, osnovni cilj ovog rada jeste sagledavanje mesta i značaja sektora poljoprivredno-prehrambenih proizvoda u spoljnotrgovinskoj razmeni Republike Srbije, kao i predlaganje mera koje bi trebalo preduzeti u pravcu podsticanja izoza i podizanja nivoa konkurentnosti posmatranog sektora na inostranom tržištu.

Poljoprivredno-prehrambeni sektor može značajno doprineti smanjenju spoljnotrgovinskog deficita i dinamiziranju izvoznih aktivnosti nacionalne ekonomije. Međutim, potencijali ovog sektora još uvek nisu u potpunosti iskorišćeni. Iako izvoz poljoprivredno-prehrambenog sektora ima dominantno mesto u strukturi domaćeg izvoza, njegova konkurentnost je još uvek na niskom nivou, pa se povećanje konkurentnosti i stepena obrade ovih proizvoda nameću kao ključni izazovi u budućnosti.

Ključne reči: izvoz, poljoprivredni i prehrambeni sektor, globalizacija, međunarodna konkurencija.

5 Profesor, dr Dejan Đurić, Visoka poslovna škola strukovnih studija Novi Sad, Vladimira Perića Valtera br. 4, 21000 Novi Sad, Republika Srbija, telefon: +381 638057 420; e-mail:ddjuric971@gmail.com

6 Profesor, dr Jelena Ristić, Visoka poslovna škola strukovnih studija Blace, Kralja Petra I br. 70, 18420 Blace, Republika Srbija, telefon: +381 63404 202; e-mail:jelenazristic@yahoo.com

7 Profesor, dr Dragana Đurić, Visoka poslovna škola strukovnih studija Blace, Kralja Petra I br. 70, 18420 Blace, Republika Srbija, telefon: +381 658057 420; e-mail:djdragana@ikomline.net

8 Ivana Vujanić M.A., doktorant na Evropskom Univerzitetu u Beogradu, Fakultet za evropski biznis i marketing, ul. Carigradska br. 28, 11000 Beograd, Srbija. Telefon: +381 6297928 66, E-mail: ivanavujanic3@gmail.com 